Jurnal Geografi, Edukasi dan Lingkungan (JGEL) Vol. 5, No. 2, Juli 2021: 101-108

P-ISSN: 2579-8499; E-ISSN: 2579-8510

Doi: https://doi.org/10.22236/jgel. v5i2.7098

Website: http://journal.uhamka.ac.id/index.php/jgel

\title{
Analisis Pola Spasial Pesebaran Kasus Covid-19 Menggunakan Sistem Informasi Geografis Di DKI Jakarta
}

\author{
Siti Dahlia* \\ Pendidikan Geografi, FKIP, Universitas Muhammadiyah Prof. DR. Hamka, Jakarta \\ Timur, Indonesia \\ *E-mail: sitidahlia@uhamka.ac.id \\ Received: 1005 2021/Accepted: 3006 2021/ Published online: 27072021
}

\begin{abstract}
ABSTRAK
Provinsi DKI Jakarta merupakan Ibukota Negara Indonesia, sehingga merupakan pusat ekonomi, pemerintahan, perdagangan, dan lainnya, yang mengakibatkan tingginya mobilitas dan kepadatan penduduk di DKI Jakarta. Pada masa pandemi Covid-19 kasus positif di Jakarta merupakan yang tertinggi di Indonesia, sehingga menjadi episentrum penyebaran Covid-19. Berdasarkan hal tersebut, tujuan penelitian ini untuk menganalisis pola distribusi spasial kasus positif Covid-19 pada Maret hingga September tahun 2020 di DKI Jakarta menggunakan Sistem Informasi Geografis. Metode yang digunakan yaitu berbasis data sekunder terkait penduduk terpapar Covid-19 di DKI Jakarta pada Maret September Tahun 2020, yang bersumber dari laman resmi Gugus Tugas Covid-19 DKI Jakarta. Analisis pola spasial berdasarkan prinsip auto corelasi spasial dengan parameter kepadatan pemukiman, jaringan transportasi dan fasiltas umum. Teknik analisis yang data berdasarkan prinsip ketetanggaan melalui aplikasi ArcGis. Hasil penelitian menunjukkan bahwa pada Maret, pola spasial wilayah penelitian berupa Cold spot atau menyebar, sedangkan pada April sampai September terdapat titik Hot Spot yaitu mengelompok dan peningkatan kasus positif yang tinggi. Hal tersebut terjadi di beberapa kecamatan di Jakarta Barat, Jakarta Pusat, Jakarta Utara, dan Jakarta Selatan. Selain itu, pola kasus positif Covid-19 tertinggi terjadi pada area dengan kepadatan penduduk tinggi. Keberadaan fasilitas umum seperti perniagaan, layanan kesehatan, dan tempat ibadah, dan lokasi layanan transportasi seperti stasiun, bandara, dan Pelabuhan juga mempengaruhi tingginya jumlah kasus positif.
\end{abstract}

Kata Kunci: Pola Spasial, Covid-19, Sistem Informasi Geografis

\section{ABSTRACT}

Jakarta Province is the Capital City of Indonesia, and also it is the center of the economy, government, trade, and others activity. This condition has impact of high mobility and population density. During the Covid-19 pandemic, positive cases in Jakarta were the highest in Indonesia, which it caused this area to be the epicenter of the spread of Covid19. Based on this, the aim of this study was to analyze the spatial distribution pattern of positive case Covid-19 from March to September 2020 in Jakarta using the Geographic Information System. The method used is based on secondary data related to residents exposed to Covid-19 in DKI Jakarta in March-September 2020, sourced from the official website of the DKI Jakarta Covid-19 Task Force. Spatial pattern analysis is based on the principle of spatial autocorrelation with the parameters of settlement density, transportation network and public facilities. The data analysis technique is based on the 
neighboring principle through the ArcGis application. The results showed that in March, the spatial pattern of the research area was in the form of cold spots or spreading, while from April to September there were hot spots, namely clusters and a high increase in positive cases. This happened in several sub-districts in West Jakarta, Central Jakarta, North Jakarta, and South Jakarta. In addition, the pattern of the highest positive cases of Covid-19 occurred in areas with high population density. The existence of public facilities such as commerce, health services, and places of worship, and the location of transportation services such as stations, airports, and ports also affect the high number of positive cases.

Keywords: Spatial Pattern, Covid-19, Geographic Information System

\section{PENDAHULUAN}

Pandemi Covid-19 (Coronavirus Disease 2019) yang disebabkan oleh virus SARSCoV-2 (Severe Acute Respiratory Syndrome Coronavirus-2) merupakan jenis bencana non alam yang mengancam kesehatan masyarakat. Selama Maret sampai Desember Tahun 2020 terjadi peningkatan kasus positif Covid-19 yang terjadi di masyarakat Indonesia. Hal ini dikarenkan proses penyebaran virus yang cepat, dari manusia ke manusia (Yanti, Nugraha, Wisnawa, Agustina, \& Diantari, 2020). Selain itu, pandemi Covid-19 merupakan peristiwa yang mengakibatkan kematian tinggi, dan terdapat 216 negara yang telah melaporkan kasus infeksi Covid-19 (Ding, Yu, \& Cao, 2020). Hal ini menunjukkan bahwa Covid-19 merupakan bencana yang dapat menggangu kelangsungan hidup manusia karena berdampak secara langsung pada kesehatan, ekonomi, dan permasalahan social budaya masyarakat (Hermon, 2020). Indonesia merupakan Negara ke empat dengan tingkat kepadatan penduduk tertinggi di dunia, sehingga potensi keterpaparan Covid-19 dapat terjadi lebih lama dibandingkan dengan negara yang penduduknya rendah (Djalante et al., 2020). Berdasarkan data Gugus Tugas Covid-19 Republik Indonesia pada tanggal 08 Desember 2020 tercatat terdapat 586.842 kasus, 85.345 dirawat, 18.000 meninggal, dan 483.497 sembuh. Kasus tertinggi terjadi di DKI Jakarta yaitu
146.621 kasus (https://covid19.go.id/) pada 8 Desember 2020 dengan 1.861 pasien dirawat, 132.248 pasien sembuh, 2.842 orang meningal, dan 9.650 orang melakukan isolasi mandiri (corona.jakarta.go.id).

Percepatan arus urbanisasi secara global, serta peningkatan konsentrasi penduduk, menyebabkan interaksi yang lebih sering dan kompleks, ditambah rendahnya jumlah tenaga medis di negara berkembang yang menjadi kendala bagi pencegahan dan pengendalian Covid-19 (Zhou et al., 2020). DKI Jakarta merupakan area dengan tingkat kepadatan dan mobilitas penduduk yang tinggi, karena merupakan Ibu Kota Negara, sehingga sangat berisiko infeksi Covid-19 (Tosepu et al., 2020).

Sistem Informasi Geografis (GIS) memiliki peran penting dalam memberikan informasi yang signifikan melalui pemetaan risiko, prakiraan spasial, pemantauan distribusi pasokan secara spasial, dan penyediaan logistik (Pourghasemi et al., 2020). Sistem Informasi Geografis (GIS) dengan teknologi berdasarkan big data telah memainkan peran penting pada berbagai aspek, yaitu agregasi cepat dari data besar multi-sumber, visualisasi secara cepat terkait informasi epidemi, pelacakan spasial kasus yang dikonfirmasi, prediksi transmisi regional, segmentasi spasial epidemic tingkat risiko dan pencegahan, penyeimbangan dan pengelolaan pasokan 
dan permintaan sumber daya material, dan bimbingan social emosional dan penghapusan kepanikan, yang memberikan dukungan informasi spasial yang solid untuk pengambilan keputusan terkait mengukur formulasi, dan penilaian terkait efektivitas pencegahan dan pengendalian Covid-19 (Zhou et al., 2020). Selain itu, menurut Kamel Boulos \& Geraghty (2020), teknologi Sistem Informasi Geografis mampu meningkatkan penyebaran data dan informasi secara real time untuk mendukung kebijakan dalam penanggulangan bencana. Adanya aplikasi pemetaan terkait distibusi kasus Covid-19 secara digital dapat membantu pihak pihak yang berkepentingan untuk mendapatkan informasi secara aktual tentang kondisi daerah berdasarkan titik koordinat (Fahri, 2020).

Menganalisis karakteristik spasial dan temporal penyebaran kasus Covid-19 merupakan teknik efektif untuk menentukan tindakan pencegahan dan pengendalian pada daerah yang berisiko tinggi (Xie et al., 2020). Analisis spasial temporal dinamika Covid-19 sangat penting untuk mitigasi suatu bencana, karena membantu menjelaskan sejauh mana dampak pandemi dan dapat membantu pengambilan keputusan, perencanaan dan tindakan masyarakat (Franch-Pardo, Napoletano, RoseteVerges, \& Billa, 2020). Analisis pola spasial Covid-19 berbasis cluster di Korea Selatan sudah dilakukan dengan hasil pola spasial cluster mengalami perubahan dan durasi cluster menjadi lebih pendek dari waktu ke waktu (Kim \& Castro, 2020). Berdasarkan hal tersebut, artikel membahas analisis pola distribusi spasial Covid-19 di DKI Jakarta mengunakan Sistem Informasi Geografis.

\section{METODE PENELITIAN} Lokasi dan Waktu Penelitian

Penelitian dilakukan di wilayah Provinsi DKI Jakarta, dengan luas 661,52 $\mathrm{km}^{2}$. Secara astronomis wilayah penelitian terletak diantara $106^{\circ} 22^{\prime} 42^{\prime}$ ' $-106^{\circ} 58^{\prime} 188^{\prime}$ ' BT, dan 6 22' 00' - 6'22'45 LS (Gambar 1).Waktu penelitian dilaksanakan pada Bulan Maret-September 2020.

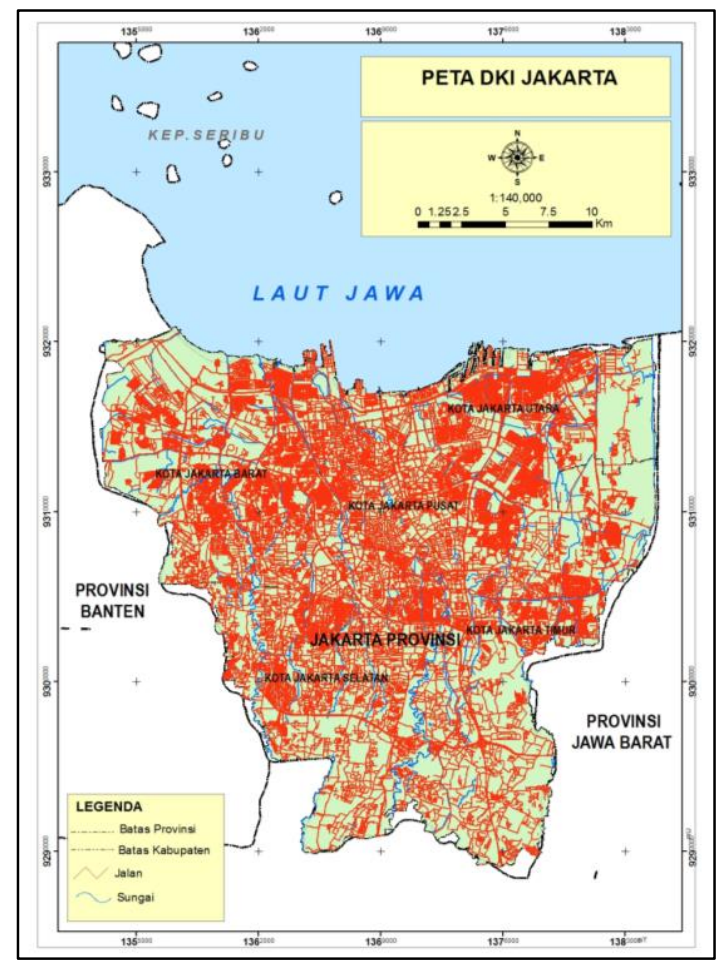

Gambar 1. Lokasi Penelitian

\section{Populasi dan Sampel}

Populasi dalam penelitian ini yaitu Seluruh penduduk wilayah DKI Jakarta yang terbagi menjadi 5 Kota Madya yaitu Jakarta Pusat, Timur, Barat, Selatan, dan Utara. Metode penentuan sampel dalam penelitian ini yaitu melalui metode sensus, yaitu seluruh penduduk di DKI Jakarta yang terpapar positif Covid-19 pada Maret sampai September Tahun 2020. Unit analisis dalam penelitian ini adalah penduduk terpapar positif Covid-19 di 261 Kelurahan. 


\section{Metode Pengumpulan Data}

Metode pengumpulan data dalam penelitian ini yaitu berbasis data sekunder. Data yang dikumpukan terkait penduduk terdampak positif Covid-19 di DKI Jakarta secara pada Maret - September Tahun 2020, yang bersumber dari laman: https://corona.jakarta.go.id.

\section{Teknik analisis data}

Analisis pola spasial digunakan dalam menganalisis data berdasarkan prinsip autocorelasi secara spasial. Parameter yang digunakan diantaranya lokasi keterpaparan kasus positif Covid19, kepadatan pemukiman, jaringan transportasi dan sebaran fasiltas umum. Analisis menggunakan aplikasi ArcGis menggunakan prinsip ketetanggaan.

\section{HASIL DAN PEMBAHASAN}

Analisis distribusi pola spasial Covid-19 di DKI Jakarta mengacu pada (Abidin, 2020), yaitu berdasarkan analisis cold spot (kejadian positif Covid-19 tingkat rendah dan pola menyebar) dan hot spot (kejadian positif Covid-19 tingkat tinggi dan pola mengumpul). Berdasarkan data analisis distribusi spasial kasus Covid19 di DKI Jakarta pada Maret sampai September tahun 2020 menunjukkan bahwa pada Maret 2020 pola distribusi spasial di DKI Jakarta menunjukkan pola cold spot, yaitu pola yang menunjukkan terdapat kasus positif Covid-19 di beberapa kelurahan yaitu 177 kelurahan dan 85 kelurahan belum teridentifikasi kasus positif. Selain itu, pola kasus Covid19 pada Maret 2020 bersifat pola menyebar (Gambar 2). Hal ini sebagai identifikasi pada Maret 2020 di DKI Jakarta kasus positif Covid-19 masih rendah, hal ini dapat di identifikasi masih rendahnya upaya pemerintah dalam melakukan tracing.

Selanjutnya, setelah Maret yaitu bulan April hingga September kasus positif Covid-19 di DKI Jakarta menunjukkan beberapa titik terjadi hot spot yaitu kejadian positif Covid-19 tinggi dan pola mengumpul. Pola titik hot spot terjadi di beberapa Kecamatan di Jakarta Pusat, Jakarta Barat, Jakarta Selatan, dan Jakarta Utara yaitu Kecamatan Cengkareng, Tambora, Gambir, Palmerah, Tanah Abang, Menteng, Senen, Kemayoran, Cempaka Putih, Tebet, Mampang Prapatan, Pademangan, Koja, Tanjung Priok, Cilincing, dan Kelapa Gading. Kondisi tersebut dapat di identifikasi karena wilayah tersebut merupakan pusat aktifitas bisnis DKI Jakarta, dan area dengan padat penduduk.

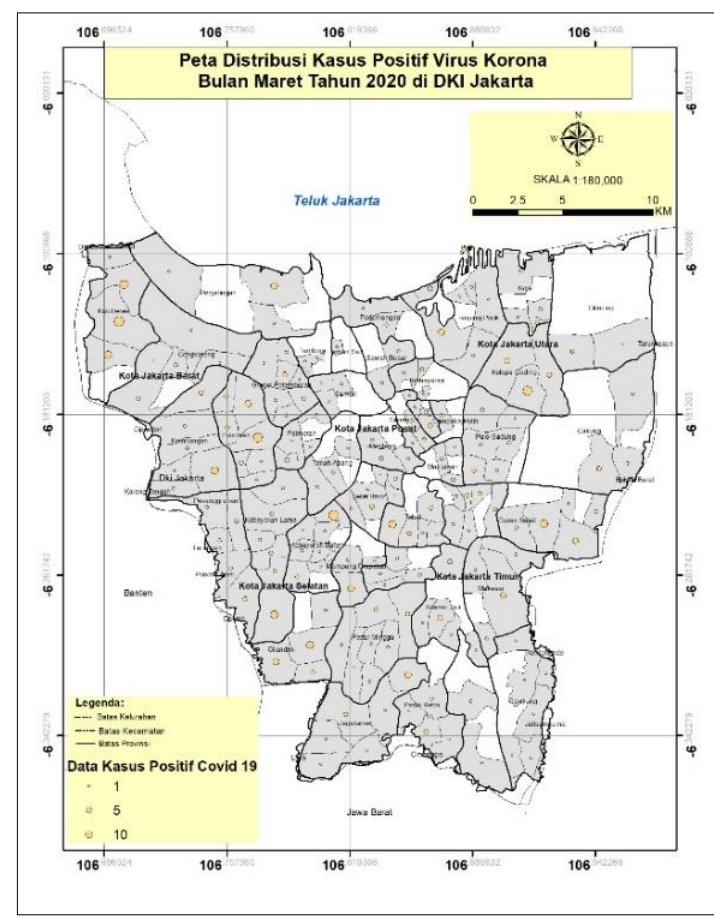

Gambar 2. Pola Distribusi Spasial Kasus Positif Covid-19 Bulan Maret

Selanjutnya pola sebaran kasus positif Covid-19 berdasarkan kepadatan penduduk menunjukkan pola hot spot atau pola dengan kasus positif Covid-19 tinggi cenderung mengelompok terjadi pada wilayah dengan kepadatan penduduk tinggi yaitu $39620-95676 \mathrm{jiwa} / \mathrm{km}^{2}$. Area dengan pola cold spot atau kejadian positif Covid-19 rendah dan pola menyebar terdapat di Keluarahan dengan kepadatan 
penduduk lebih rendah yaitu berkisar 1.213-13.004 jiwa/ $\mathrm{km}^{2}$ (Gambar 4). Hal ini dapat di identifikasi bahwa tingkat kepadatan penduduk yang tinggi dapat mempengaruhi peningkatan kasus Positif Covid-19. Hal ini sesuai dengan teori yang dinyatakan oleh (Ren et al., 2020) bahwa area perkotaan yang padat dan aktivitas tinggi berisiko terinfeksi Covid-19 lebih tinggi. Wilayah dengan kepadatan penduduk tinggi seperti Kecamatan Tambora dan Taman Sari berpotensi adanya interaksi antar penduduk yang massive, sehingga berpotensi tingginya penularan Covid-19 di masyarakat. Hal ini mengakibatkan pada area tersebut membentuk pola Hot Spot.
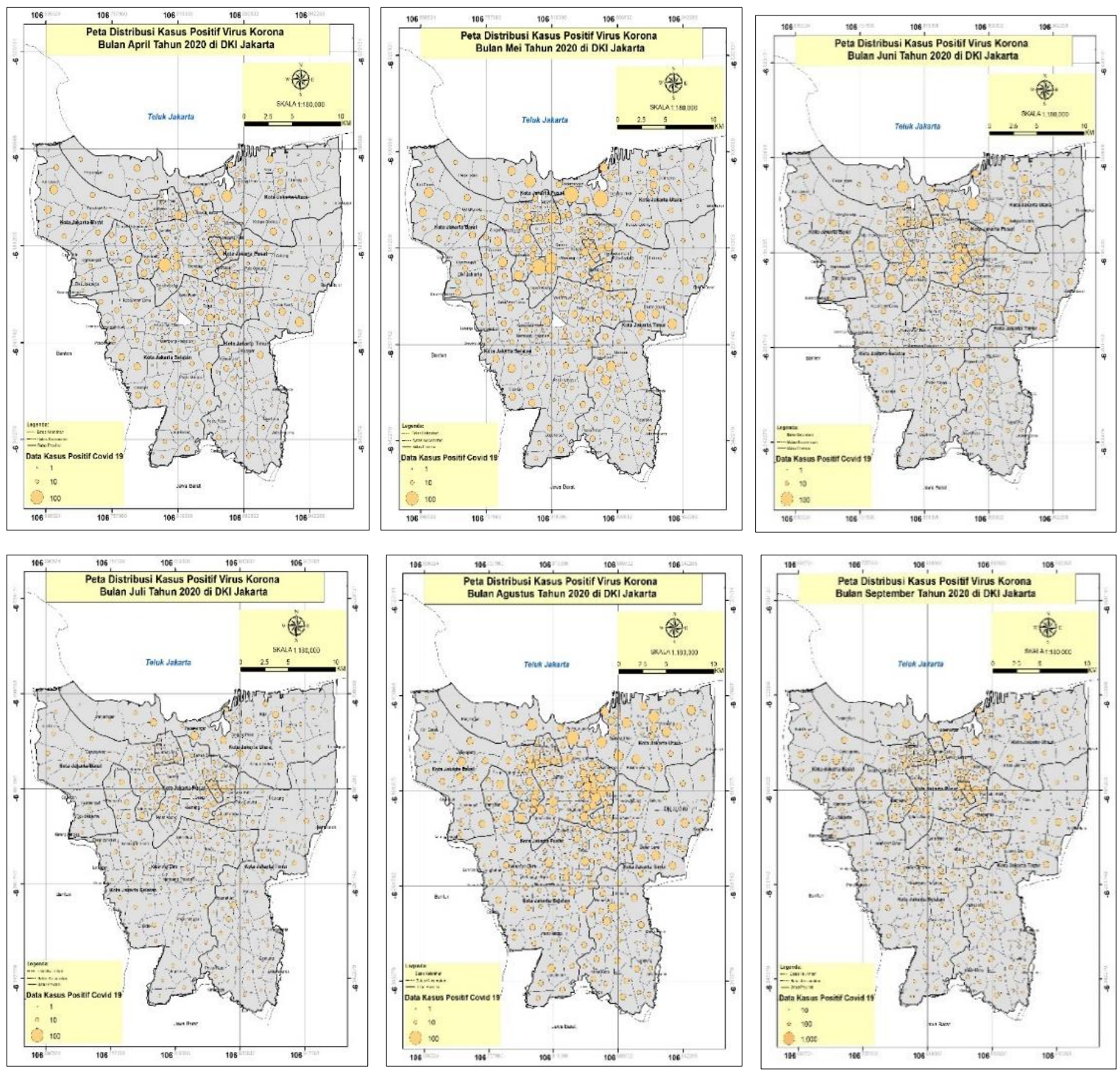

Gambar 3. Pola Distribusi Spasial Kasus Positif Covid-19 April-September tahun 2020 
Selanjutnya, kasus positif Covid19 berdasarkan data lokasi titik fasilitas umum yaitu pada penelitian ini terbatas pada fasilitas tempat ibadah, perniagaan, dan fasilitas kesehatan. Data menunjukkan bahwa pola area dengan kasus positif Covid-19 tinggi yaitu zona merah atau terdapat 201-581 kasus positif terdapat di area yang memiliki banyak fasilitas umum. Namun, berbeda dengan area kasus positif rendah yaitu dengan kategori $0-100$ orang memiliki lebih sedikit fasilitas umum (Gambar 5). Hal ini dapat menunjukan bahwa fasilitas umum seperti layanan kesehatan, tempat ibadah dan perniagaan berpotensi menjadi tempat penularan Covid-19. Kondisi tersebut dikarenakan masih banyak tempat umum yang belum menerapkan protokol kesehatan, sehingga tingginya potensi penularan Covid-19 antar manusia (Yanti et al., 2020).

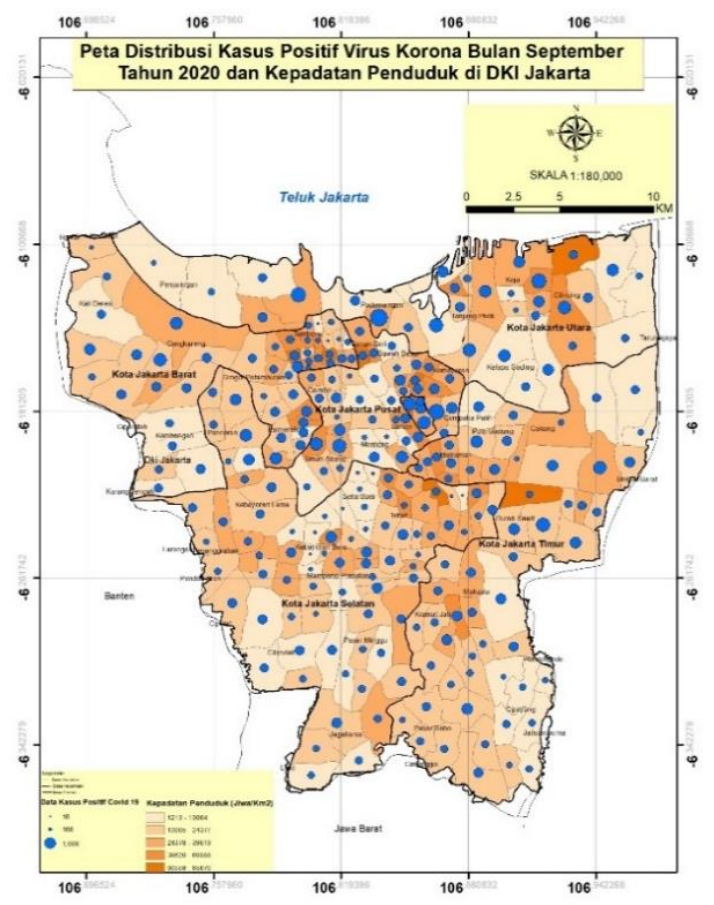

Gambar 4. Pola Distribusi Spasial Kasus Positif Covid-19 September 2020 Berdasarkan Tingkat Kepadatan Penduduk
Tingginya kasus positif Covid-19 ditinjau melalui data lokasi transportasi yaitu stasiun kereta api, pelabuhan, dan bandara di DKI Jakarta menunjukkan bahwa area dengan kasus positif sedang dan tinggi mayoritas berada deket dengan stasiun kereta, pelabuhan, dan bandara (Gambar 6). Hal ini dapat mengidentifikasi bahwa pusat transportasi menjadi sebagai fasilitas umum yang dikunjungi oleh berbagai masyarakat, dan merupakan tempat keramaian, sehingga potensi penularan Covid-19 antara manusia tinggi. Meskipun pada moda transportasi tersebut sudah menerapkan protokol kesehatan, akan tetapi tingginya pengguna KRL di DKI Jakarta berpotensi sebagai salah satu tempat penularan Covid-19.

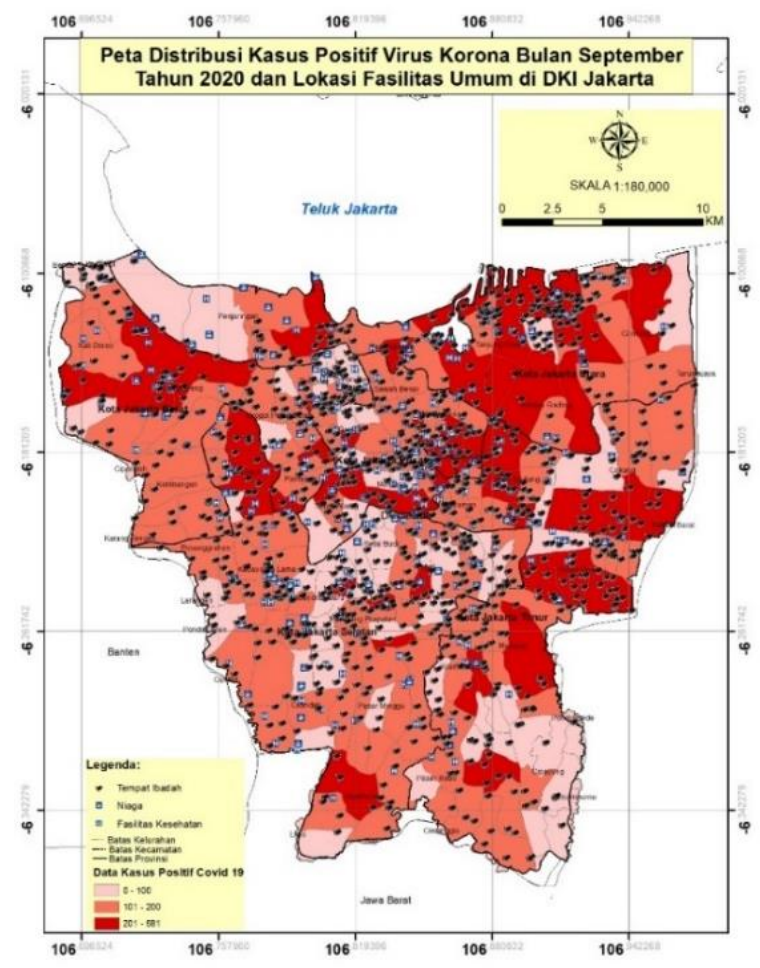

Gambar 5. Pola Distribusi Spasial Kasus Positif Covid-19 Bulan September Berdasarkan Lokasi Fasilitas Umum 


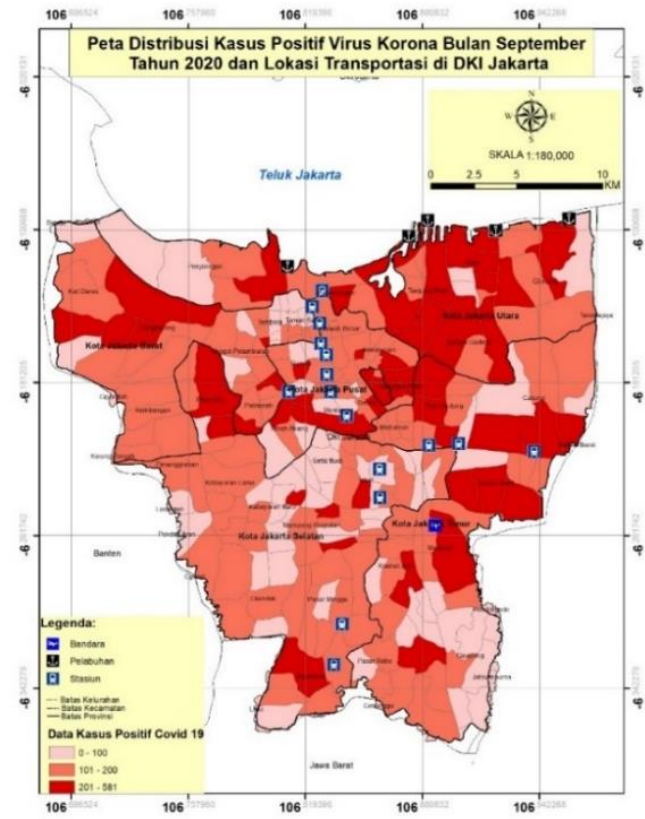

Gambar 6. Pola Distribusi Spasial Kasus Positif Covid-19 September Berdasarkan Jaringan moda Transportasi

\section{KESIMPULAN}

Berdasarkan analisis pola spasial menunjukkan bahwa pada wilayah penelitian pada Bulan Maret memiliki pola Cold spot atau menyebar, sedangkan Bulan April sampai September terdapat titik Hot Spot yaitu beberapa Kecamatan di Jakarta Barat, Pusat, Utara, dan Selatan. Selain itu, secara pola kasus positif Covid19 tertinggi pada area dengan kepdatan penduduk tinggi, tingginya keberadaan fasilitas umum seperti perniagaan, layanana kesehatan, dan tempat ibadah, dan lokasi layanan transportasi seperti stasiun, bandara, dan pelabuhan.

\section{DAFTAR PUSTAKA}

Abidin, H. Z. (2020). Pemanfaatan Informasi Geospasial Untuk Manajemen Pengurangan Resiko Bencana Non-Alam Covid-19 Prof. $\mathrm{Dr}$. Hasanuddin $Z$. Abidin. (June). https://doi.org/10.13140/RG.2.2.205 71.80166.

Ding, J., Yu, C. W., \& Cao, S. J. (2020). HVAC systems for environmental control to minimize the COVID-19 infection. Indoor and Built Environment, 29(9), 1195-1201. https://doi.org/10.1177/1420326X20 951968.

Djalante, R., Lassa, J., Setiamarga, D., Sudjatma, A., Indrawan, M., Haryanto, B., Warsilah, H. (2020). Review and analysis of current responses to COVID-19 in Indonesia: Period of January to March 2020. Progress in Disaster Science, 6, 100091.

https://doi.org/10.1016/j.pdisas.2020. 100091.

Fahri, M. U. (2020). Melihat Peta Penyebaran Pasien Covid-19 Dengan Kombinasi Qgis Dan Framework Laravel. Jurnal Teknologi Terpadu, 6(1), 25-30.

Franch-Pardo, I., Napoletano, B. M., Rosete-Verges, F., \& Billa, L. (2020). Spatial analysis and GIS in the study of COVID-19. A review. Science of the Total Environment, 739, 140033. https://doi.org/10.1016/j.scitotenv.20 20.140033.

Hermon, D. (2020). How Is Covid-19 Mitigation In Indonesia? Introduction From Editor In Chief How Is Covid-19 Mitigation In Indonesia? Sumatra Journal of Disaster, 4(1). https://doi.org/10.24036/sjdgge.v4i1. 320.

Kamel Boulos, M. N., \& Geraghty, E. M. (2020). Geographical tracking and mapping of coronavirus disease COVID-19/severe acute respiratory syndrome coronavirus 2 (SARSCoV-2) epidemic and associated events around the world: How 21st century GIS technologies are supporting the global fight against outbr. International Journal of Health Geographics, 19(1). https://doi.org/10.1186/s12942-02000202-8. 
Kim, S., \& Castro, M. C. (2020). Spatiotemporal pattern of COVID-19 and government response in South Korea. International Journal of Infectious Diseases, 98, 328-333. https://doi.org/10.1016/j.ijid.2020.07 .004

Pourghasemi, H. R., Pouyan, S., Farajzadeh, Z., Sadhasivam, N., Heidari, B., Babaei, S., \& Tiefenbacher, J. P. (2020). Assessment of the outbreak risk, mapping and infection behavior of COVID-19: Application of the autoregressive integrated-moving average (ARIMA) and polynomial models. PLoS ONE, 15 (7 July). https://doi.org/10.1371/journal.pone. 0236238.

Tosepu, R., Gunawan, J., Savitri, D., Ode, L., Imran, A., \& Lestari, H. (2020). Correlation between weather and Covid-19 pandemic in Jakarta, Indonesia. Science of the Total Environment, 725(January).
Xie, Z., Qin, Y., Li, Y., Shen, W., Zheng, Z., \& Liu, S. (2020). Spatial and temporal differentiation of COVID19 epidemic spread in mainland China and its influencing factors. Science of the Total Environment, 744 , 140929. https://doi.org/10.1016/j.scitotenv.20 20.140929.

Yanti, N. P. E. D., Nugraha, I. M. A. D. P., Wisnawa, G. A., Agustina, N. P. D., \& Diantari, N. P. A. (2020). Gambaran Pengetahuan Masyarakat tentang Covid-19 dan Perilaku Masyarakat di Masa Pandemi Covid19. Jurnal Keperawatan Jiwa, Vol. 8 No.(3), 485-490.

Zhou, C., Su, F., Pei, T., Zhang, A., Du, Y., Luo, B., ... Xiao, H. (2020). COVID19: Challenges to GIS with Big Data. Geography and Sustainability, 1(1), 77-87. https://doi.org/10.1016/j.geosus.2020 .03 .005 